\title{
Pregando sobre o amor aos frágeis corações de cera: o Sermão do Mandato do Padre Antônio Vieira (Lisboa, 1643)
}

\author{
Preaching about love to the fragile hearts of wax: Father \\ Antônio Vieira's Sermão do Mandato(Lisbon, 1643)
}

\author{
Elaine Cristina Deckmann Fleck ${ }^{1}$ \\ Mauro Dillmann Tavares ${ }^{2}$
}

RESUMO

\begin{abstract}
Neste artigo, analisamos o Sermão do Mandato, proferido pelo padre jesuíta Antônio Vieira aos enfermos do Hospital Real de Lisboa, no ano de 1643, destacando as representações do amor nele presentes e as influências que obras literárias, teológico-morais e filosóficas exerceram sobre a percepção que o pregador jesuíta apresenta sobre as doenças do corpo e da alma e, em especial, sobre os remédios que promoveriam a cura dos enfermos de amor.
\end{abstract}

Palavras-chave: Antônio Vieira. Sermão do Mandato. Amor: doenças do corpo e da alma.

\section{ABSTRACT}

In this article, we analyze the Sermão do Mandato, delivered by jesuit priest Antônio Vieira to the diseased of the Royal Hospital of Lisbon, in the year of 1643, highlighting the representations of love

\footnotetext{
1 Doutora em História pela Pontifícia Universidade Católica do Rio Grande do Sul (PUC-RS), professora da Universidade do Vale do Rio dos Sinos (Unisinos), São Leopoldo, RS, Brasil. Bolsista de produtividade científica do CNPq, nível 2, coordenadora do Convênio de Cooperação Acadêmica entre Grupos de Estudos de Historia do Brasil e Portugal (GEHBP), firmado entre a Universidad de Buenos Aires (UBA) e a Universidade do Vale do Rio dos Sinos e integrante dos Grupos de Pesquisa-CNPq Jesuítas nas Américas e Imagens da Morte: a morte e o morrer no mundo ibero-americano. E-mail: ecdfleck@terra.com.br.

2 Doutor em História pela Universidade do Rio dos Sinos (Unisinos). São Leopoldo, RS, Brasil. Integrante do GT História das Religiões e Religiosidades/Anpuh-RS e do Grupo de Pesquisa do CNPqImagens da Morte: a morte e o morrer no mundo ibero-americano". E-mail: maurodillmann@hotmail.com.
} 
present in it and the influence that literary, theological, moral and philosophical works had on the perception the Jesuit preacher presents about the sicknesses of the body and the soul and, especially, about the remedies that would promote the cure of the love sick.

Keyword: Antônio Vieira. Sermão do Mandato. Love: sicknesses of the body and the soul.

Atreve-se o tempo a colunas de mármore, quanto mais a corações de cera. Padre Antônio Vieira

\section{Vieira e o Sermão sobre os remédios de amor e o amor sem remédio}

Em geral, a produção historiográfica tem abordado o amor a partir da sua conotação sexual e erótica, vivenciada no casamento ou fora dele. ${ }^{3}$ Já filósofos, como Georg Simmel (1993) e José Ortega y Gasset (1958), reconhecem que o amoré um tema muito vasto e diverso, estando além da relação afetiva entre os gêneros. Alguns estudos sociológicos recentes, como o realizado por Zygmunt Bauman, têm demonstrado que as exigências sentimentais pós-modernas demandam pouco esforço no aprendizado da "arte de amar", sendo cada vez mais comuns as efêmeras "experiências amorosas" (BAUMAN, 2004, p. 22).

Dentre os inúmeros sermões que o padre jesuíta Antônio Vieira ${ }^{4}$ escreveu no século XVII, em um deles - o Sermão do Mandato, de $1643^{5}$, proferido aos doentes do Hospital Real de Lisboa ${ }^{6}$ - o pregador refere-se a um frágil amor, que resulta do fervor da afeição e do empenho do coração, desprovido, portanto, de conotação sexual e/ou conjugal. É sobre as representações do amor presentes neste sermão do jesuíta Vieira que nos debruçamos neste

3 Priore (2005). Emoções e sentimentos como o amor têm já há algum tempo pautado vários estudos historiográficos e sob diferentes perspectivas. Georges Duby (1989) destacou a relação existente entre "amor" e "afetividade conjugal" na França medieval; Luís Mott (2001) abordou o amor entre pessoas do mesmo gênero; Mary Del Priore (2005) destacou práticas e imaginários amorosos no Brasil. O historiador inglês Théodore Zeldin, na década de 1980, destacava a imprecisão do conceito de "amor", vinculando-o à atração, sedução e sexualidade. Mas ressaltava a importância da história das emoções para a elucidação do significado, vocabulário, comportamento e atitudes de sentimentos particulares, entre eles, o amor. Defendia ainda o estudo do "amor em si", suas manifestações e suas ambiguidades (ZELDIN, 1992, p. 271).

4 O padre jesuíta Antônio Vieira (1608-1697) viveu boa parte de sua vida no Brasil, foi orador de grande prestígio, confessor, diplomata, conselheiro de D. João IV e "superior de missão catequética" (HANSEN, 2003, p. 15). Como um homem "do poder real", como bem destacou Hansen (2003, p. 15), Vieira foi, "antes de tudo", um "defensor da Coroa" e da "nação portuguesa", influenciando até mesmo decisões régias. De grande capacidade retórica, foi um grande e eloquente orador, defensor do catolicismo e pregador de muitos sermões (CESAR, 2011, p. 6-7; VAINFAS, 2011, p. 25).

5 Valemo-nos de uma edição portuguesa do Sermão do Mandato de 1643, do Padre Antônio Vieira, prefaciada pelo padre Joaquim Carreira das Neves, datada de 2011. Vieira (2011).

6 Este hospital era também conhecido como Hospital Real de Todos os Santos, tendo sido construído entre os anos de 1492 e 1504, por iniciativa do rei D. João II "a fim de substituir os 43 albergues e hospitais que antes juncavam a cidade", surgindo "para responder a problemas da época, em nome de uma [...] vontade de controle e organização [...] dos pobres e da pobreza". O hospital funcionou até o século XVIII, pois nos anos 1750 foi consumido por um incêndio e também pelo terremoto. (RAMOS, 1993, p. 336) 
artigo, com o propósito de contribuir tanto para a produção dedicada à reconstituição da trajetória e à análise da obra de um dos mais ilustres missionários e pregadores da Companhia de Jesus, quanto para aquela que, inspirada nos estudos culturais, têm refletido sobre o amor e as sensibilidades na história.

Especialmente no século XVI, os sermões assumiram uma importância crucial para os objetivos contrarreformistas da Igreja Católica, não apenas para divulgação da fé, mas para a conversão e para o convencimento de indivíduos à "mudança de hábitos" pela "força da palavra"7 (MASSIMI, 2005, p. 13). Importante, no entanto, destacar - tal como analisou Sonia de Mancera para o contexto da evangelização na Nova Espanha - que entre o teólogo tridentino [e pós-tridentino] que pensava e o povo ignorante e analfabeto que devia viver como cristão, havia um abismo mental, emocional e vivencial (MANCERA, 1994, p. 27). Evidentemente, o sermão não era pregado apenas para analfabetos e a recepção de suas mensagens não se dava exclusivamente através da leitura, pois era através da audição dos sermões pregados nas igrejas que a mensagem cristã alcançava e instruía as almas.

Definidos como ações eloquentes vinculadas à oratória e como discurso construído no campo da retórica e relacionado à linguística e à hermenêutica ${ }^{8}$, os sermões obedeciam a uma estrutura ordenada, definida a partir de uma introdução, passando pela explanação do tema abordado, cuja argumentação apoiava-se em passagens bíblicas e em escritos de santos e teólogos, até chegar à conclusão. Neste sentido, os sermões escritos pelo padre Vieira se aproximavam de outros produzidos no século XVII e que também ressaltavam as dualidades e contrastes entre céu/inferno, salvação/condenação, Deus/Demônio, santo/pecador e entre beleza/feiúra. ${ }^{9}$ Em termos literários, a escrita e o vocabulário, longe de se apresentarem com simplicidade, apelavam à prolixidade, às inversões e aos conceitos e problemáticas aparentemente difíceis, não descuidando, no entanto, da clareza da língua, da concisão, da erudição e do "engenho"10.

Em relação, especificamente, aos sermões do mandato, era prática comum no século XVII que religiosos escrevessem sobre o "mandamento do amor" e sobre o significado do amor de Cristo $^{11}$ que morreu, justamente, por ter amado muitíssimo aos homens (LIMA,

7 Sobre os sermões como importantes instrumentos de formação de sujeitos cristãos no contexto europeu de fim da Idade Média, ver Thomas, (1991, p. 135). Para uma análise dos sermões como "planejado uso da palavra" nos discursos jesuítas na América Colonial espanhola do século XVIII, ver Cerveira (2008, p. 47-48). Sobre os sermões como recursos de divulgação de "relatos edificantes" e conversão de indígenas na América espanhola do século XVII, ver Fleck (1999, p. 90101).

8 Pécora (1994, p. 171) e Saraiva (1985). O Vocabulário Portuguez e latino, organizado pelo padre Raphael de Bluteau, no início do século XVIII, assim definiu, sucintamente, a palavra sermão: "oração evangélica, arrazoado, ou discurso de orador eclesiástico".

$9 \mathrm{Em}$ relação à morte, por exemplo, veja-se a ênfase dada ao macabro em Portugal, mediante a exposição de esqueletos e ossos para incitar os indivíduos à meditação sobre o morrer. Rodrigues (2007, p. 57).

10 De acordo com os estudos historiográficos e literários, os termos "engenhoso" e "engenho", associados a Vieira, são entendidos como sinônimo de qualidade intelectual para a retórica poética. Ver Hansen (2003, p. 25-26). Segundo Umberto Eco, o "engenho" compreende "dois talentos naturais: perspicácia e versatilidade" (ECO, 2010, p. 229).

11 O jesuíta baiano Eusébio de Matos (1629-1692) foi contemporâneo de Vieira, sendo comparado a ele por muitos estudiosos, devido à forma como manuseava a língua portuguesa. Foi também pregador e autor de vários sermões; um 
2002, p. 202). Entre os anos de 1643 e 1670, o padre Vieira escreveu seis sermões sobre a perfeição do amor de Cristo e sobre a imperfeição do amor humano (LIMA, 2002, p. 200), sendo os cinco primeiros proferidos em Portugal e o último na Itália. Apesar de não terem sido destinados ao mesmo público ${ }^{12}$, todos se caracterizam pela erudição e pelo emprego de complexos jogos de palavras, visando a persuadir e a convencer os ouvintes. ${ }^{13}$

No sermão de 1643, que analisamos mais detidamente neste artigo, Vieira se refere ao amor como uma doença incurável ${ }^{14}$ e recomenda o emprego de "remédios"15 - tempo, ausência, ingratidão e "melhorar[sic]do objeto" - para a cura dos enfermos de amor (LIMA, 2002, p. 202), detendo-se na explicitação da eficácia de cada um deles para a eliminação desse sentimento das almas pecadoras. Ao escrevê-lo, Vieira agregava uma experiência de praticamente dez anos de púlpito, se consideramos o ano de sua ordenação sacerdotal, ocorrida em 10 de dezembro de 1634, e, ainda, a adquirida como professor de Retórica no Colégio de Olinda ${ }^{16}$ (CASTRO; MENDES, 2007, p. 14), aspectos que apontam para a necessidade de relativizarmos a importância dada ao contexto político e às experiências vividas pelo jesuíta exclusivamente no ano de 1643.

deles, intitulado "sermão do Mandato", foi publicado após a sua morte, no ano de 1694. José Américo Miranda e Maria Cecília Boechat, ao reeditarem este sermão, em 1999, destacaram os significados de "mandato": "é o contrato pelo qual uma pessoa é encarregada de praticar certos atos em nome de outra, que lhe delega poderes para isso. Mandato é o nome da cerimônia religiosa que se celebra na quinta-feira santa, na qual são lavados os pés de doze pobres. Essa cerimônia recorda a última ceia. A atitude de lavar os pés a seus apóstolos foi seguida pelas seguintes palavras de Jesus, segundo São João (13:12-15): 'Sabeis o que vos fiz? Vós me chamais Mestre e Senhor, e dizeis bem, porque eu o sou. Logo, se eu, vosso Senhor e Mestre, vos lavei os pés, também vós deveis lavar os pés uns aos outros".

12 Os Sermões do Mandato foram pregados nos anos de 1643, 1645, 1650, 1655 e 1670. Os de 1645 e 1650 foram proferidos na Capela Real; o de 1655, na Misericórdia de Lisboa (há outro, pregado no mesmo ano) e o de 1670, em Roma, na igreja de Santo Antônio dos Portugueses (MAZIERO, 2004, p. 14).

13 Ao destacar a importância que assumiam os evangelhos, Vieira dizia: "Tudo o que acabo de dizer é filosofia não minha, senão do mesmo Cristo" (VIEIRA, 2011, p. 37).

14 A noção de cura do amor também esteve presente em outros escritores do século XVII, como se pode constatar nas obras do francês Jean de La Bruyére (1645-1696): "O amor que brota subitamente é o que mais demora para curar" (Enciclopédia do Amor).

150 termo "remédios" foi muito empregado na Europa moderna, especialmente, na literatura religiosa, para se referir não apenas à cura dos corpos, mas também à cura dos males que afligiam os sentimentos, as relações sociais e, principalmente, a alma dos indivíduos. Eram comuns, portanto, as recomendações de "remédios" para eliminação de pecados, "remédios" para maus casamentos, "remédios" para salvação das almas, "remédios" para os males da alma, dentre os quais, já tivemos a oportunidade de analisar em outros textos. Ver Fleck e Dillmann $(2012,2013)$.

16 A educação jesuítica - herdeira das tradições escolásticas e humanísticas - visava, sobretudo, à formação de "bons cristãos", disseminando, através de um Plano de estudos, normas morais, valores e práticas associados ao universo cristão-católico. Tanto as Constituições da Companhia de Jesus, quanto a Ratio Studiorum evidenciam a importância do ensino de Gramática, Retórica e Humanidades para a formação de "bons cristãos", cumpridores de seus deveres e dotados das virtudes da sabedoria, justiça, coragem e moderação [o autocontrole, visando à harmonia dos apetites individuais]. Nos colégios da Companhia de Jesus, o último ano dos estudos inferiores era dedicado à Retórica, que, de acordo com a Ratio, previa lições de preceitos de oratória, estilo e erudição, privilegiando uma "prática da língua", que não descuida da sofisticação teórica - evidenciada nas citações dos humanistas clássicos - agregada de regras de conselho e comportamento. "A retórica aristotélica e ciceroniana foram os principais instrumentos adotados para constituir um estilo de vida em que a inculcação de hábitos nobres (entendendo-se "nobreza" com o duplo sentido de "estamento" e "virtude") foram a meta principal." Ao atuar como professor de Retórica, Vieira deve ter, com certeza, procurado semear sentimentos de piedade e devoção e cultivar virtudes em seus alunos, a fim de levá-los a "distinguir o verdadeiro do falso e estabelecer o meio-termo justo que é próprio da prudência", base para todas as virtudes morais. (HANSEN, 2006, p. 135, 156). Em seus sermões, Vieira aplicaria exemplarmente os pressupostos da Retórica que ensinava: a inculcação de bons hábitos e de virtudes e a correção de eventuais vícios. 
É plausível supor que este sermão tenha sido, assim como muitos outros de sua autoria, revisado e reescrito por Vieira, ${ }^{17}$ logo após o seu pronunciamento, tanto para utilização de passagens em outros sermões do mandato, quanto para sua posterior publicação. ${ }^{18}$ Ao serem publicados em 1685, os sermões de Vieira alcançaram o público letrado, religioso e leigo devoto e, assim como diversas outras obras da literatura moderna, apresentavam "exemplos a imitar", sendo que o amor - seus tipos, suas características, suas forças e fraquezas deveriam "ficar inscritas na mente dos leitores" (CARDIM, 1999, p. 27), mediante sutileza e acuidade "capaz de surpreender e penetrar a alma do ouvinte" (ECO, 2010, p. 229). Aos ouvintes deste sermão - em sua maioria, pobres e doentes internados no hospital ${ }^{19}$ - e aos seus potenciais leitores - nobres e letrados portugueses - Vieira apresentava a sua interpretação do amor, um sentimento a ser cultivado, alimentado e fortalecido pelos homens, a partir da moral cristã. Empenhado em convencê-los sobre a eficácia dos "remédios de amor", o jesuíta recorreu a palavras como "padecimento", "sofrimento", "chagas", "enfermidades" e "dores", o que parece apontar para a preocupação do pregador em adequar o sermão ao local e ao público a que se destinava. ${ }^{20}$

\section{Pregando aos doentes do Hospital Real de Lisboa}

Durante os séculos XVI e XVII, Lisboa não apenas apresentou expressivo crescimento demográfico - motivado, em grande medida, pelo lucrativo comércio ultramarino -, como se viu assolada por epidemias como o tifo, a difteria, a peste bubônica, a febre tifóide e a malária (febre terçã). Situação que seria agravada pela escassez de alimentos e pela alta dos preços, especialmente, a partir do declínio dos lucros advindos da produção açucareira no Brasil, no período imediatamente após a Restauração, em 1640 (RODRIGUES, 2007, p. 47).

17 Embora seja necessário considerar que o padre Vieira reescrevesse os seus sermões, buscando o aperfeiçoamento de sua escrita (LIMA, 2002, p. 201), era na pregação que o jesuíta comovia, despertando sentimentos, reforçando a fé nos dogmas e convencendo seus ouvintes. Segundo Aníbal de Castro, para atender as inúmeras solicitações, "não é de crer que Vieira, como grande parte dos pregadores seus contemporâneos, tivesse tempo e lugar propício antes de os pronunciar, até porque os dizia, as mais das vezes, [...] de cor" (CASTRO; MENDES, 2007, p. 14).

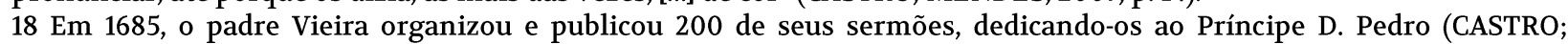
MENDES, 2007, p. 7). Já desde 1675, o padre Vieira apoiava o regente Dom Pedro - que assumiu o trono português como regente, em 1668, sucedendo ao irmão Afonso VI -, como fica evidenciado no título que deu a uma obra sua de 1678 , Memorial ao príncipe regente $d$. Pedro II, e no empenho com que convencia "os reis de que eles eram mesmo reis" (VAINFAS, 2011, p. 252).

19 Os hospitais eram usualmente percebidos como lugar de pobreza e de abrigo para pobres, concepção que se manteve no século XVIII, como se pode constatar na definição dada para hospital que encontramos no Vocabulário de Bluteau: "lugar público, em que se curam doentes pobres" de modo "tão unido [...] com o culto Divino [e] o amor do próximo". No hospital, complementa Bluteau, "se agasalham e se sustentam pobres". (BLUTEAU, 1712-1728, t. 4. p. 65).

20 Os sermões de Vieira tinham, entre outros objetivos, o de apresentar uma interpretação do texto bíblico. O pregador, enquanto um representante da Igreja e de Deus, era tido como conselheiro espiritual, a quem cabia alertar os fieis para as consequências de atos e sentimentos pecaminosos, de modo a orientá-los à vida venturosa, garantindo, assim, a salvação de suas almas (SEIDE, 2002, p. 94). A "Época Moderna" era, assim, "terreno privilegiado para fornecer pautas de comportamento perfeito" a leitores e ouvintes (SANTOS, 2006, p. 189). 
Destino de muitos dos doentes, famintos e empobrecidos ${ }^{21}$ da Lisboa seiscentista, mas também de fidalgos, lavradores, comerciantes e burgueses - o Hospital Real oferecia tratamento e consolo diante da iminência da morte. Se o restabelecimento da saúde física poderia resultar da intervenção de médicos, cirurgiões, boticários e sangradores (RAMOS, 1993, p. 341), a cura, segundo o imaginário da época, se dava pela "força da oração", à qual "se atribuía uma eficácia maior do que aos cuidados clínicos" (RAMOS, 1993, p. 346). ${ }^{22}$ No Hospital Real, as salas dos doentes e a capela que nele funcionava formavam arquitetonicamente o modelo de uma cruz, o que tornava possível a assistência dos ofícios religiosos pelos pacientes que se encontravam nas enfermarias (RAMOS, 1993, p. 338).

A atuação de religiosos como auxiliares no atendimento dos doentes era também favorecida pelo escasso corpo clínico do Hospital Real, formado por dois físicos, três cirurgiões, três enfermeiros e cinco enfermeiras (RODRIGUES, 2007, p. 78), que atendiam mais de seiscentos pacientes internados na primeira década do século XVII. Mesmo que fossem poucos, o Hospital Real concentrava, desde seu surgimento, os "práticos da medicina disponíveis", para os quais a Realeza facultava "bons salários" (RAMOS, 1993, p. 337). Entre os anos 1616 e 1617, o hospital registrou a entrada de cerca de três mil doentes, dos quais mais de seiscentos faleceram e mais de 250 permaneceram internados (RODRIGUES, 2007, p. 77). O hospital possuía, também, enfermarias específicas para os enfermos de doenças infectocontagiosas, como a lepra e a sífilis ${ }^{23}$, bem como um espaço diferenciado para o tratamento dos nobres.

O Hospital Real, certamente, recebia donativos da Coroa para a manutenção de sua botica, assim como o Mosteiro de Santa Clara, de Coimbra, que recebia especiarias e açúcar para a preparação de fórmulas terapêuticas (LEAL; FERREIRA, 2007). Sabe-se, também, que o hospital contou, desde o século XVI, com a provedoria de capelães do rei e cavaleiros da casa real, bem como, com servidores e criados escolhidos entre aqueles que serviam à família real, pois era "dever das pessoas de qualidade que assim mostravam a sua dedicação à instituição em causa" (RAMOS, 1993, p. 345-348). Encontrando-se bastante próximo do rei d. João IV desde seu retorno a Portugal em $1641^{24}$, Vieira não se limitou a oficiar missas na Capela Real, dedicando-se, assim como tantos outros sacerdotes, também ao consolo dos

210 Hospital Real de Lisboa abrigava enfermos dos mais diversos grupos sociais, funcionando também como instituição beneficente encarregada de auxiliar "pedintes andantes" e peregrinos e, ainda, de acolher e cuidar de crianças expostas (RAMOS, 1993, p. 339).

22 Vale lembrar que neste período atribuía-se à palavra um inegável caráter terapêutico, tanto que pregadores como Vieira podiam ser enquadrados na categoria de "médicos da alma" (MASSIMI, 2009).

23 No início da época moderna, as viagens marítimas fizeram com que a sífilis proliferasse em Portugal. Alarmados, alguns médicos escreveram sobre a doença, como Ruy Diaz d'Ysla, autor do Tractado contra o mal serpentino (1539), que "teve a seu cargo a enfermaria de doenças contagiosas do Hospital Real de Todos-os-Santos" (RODRIGUES, 2007, p. 76). 24 Por seu apoio à Casa de Bragança durante a Restauração, em 1640, a Companhia de Jesus passou a desfrutar de grande prestígio junto à Coroa portuguesa. Em 1641, ao receber o padre Antônio Vieira em Lisboa, D. João IV impressionou-se com sua inteligência e com sua habilidade retórica, o que o levou a buscar, de imediato, uma maior aproximação com o jesuíta. A idade aproximada - o rei era apenas quatro anos mais velho que Vieira, que contava, então, com apenas 33 anos - pode ter sido outro elemento que os aproximou (AZEVEDO, 2008, p. 71; PÉCORA, 1994, p. 225). Um ano depois, em 1642, Vieira realizaria, pela primeira vez, um sermão na Capela Real (AZEVEDO, 2008, p. 78). 
enfermos do Hospital Real, mantido pela Coroa portuguesa. Neste sermão que dirigiu a eles, Vieira procurou aproximar a noção de doença à de amor, afirmando que somente o amor divino era aquele capaz de oferecer o "remédio infalível da redenção" (BOSI, 2011, p. 4). Aos enfermos, Vieira enfatizava a noção de brevidade da vida, os "tão poucos dias" de vida humana - se comparados à eternidade da alma - de modo que seus ouvintes/leitores fizessem da necessidade de amar a Cristo um perseverante exercício nos passageiros dias de vida terrena (VIEIRA, 2011, p. 71). Para Alfredo Bosi, a intenção de Vieira era de

[...] demonstrar que a morte iminente de seus ouvintes é uma prova do amor misericordioso de Deus. Mesmo quando suas criaturas pecam excessivamente ou negligenciam as obrigações religiosas - e por isso se tornam merecedoras do martírio físico da doença -, o Criador sempre lhes oferece o remédio infalível da redenção eterna. Assim, os internos do hospital deveriam ter em mente que, assim como os sofrimentos de amor, sua precária condição física e espiritual era transitória, e seria compensada pela segunda vida, no Paraíso (BOSI, 2011, p. 4, grifo nosso).

A percepção de que os homens estavam doentes de amor, mas de um amor facilmente curável, mediante a administração dos seus contrários, remete à teoria médica hipocráticogalênica vigente no período, que estabelecia o tratamento das doenças através de agentes contrários aos seus causadores (POLETTO, 2011, p. 16). Esta teoria, também chamada de "teoria humoralista", considerava que o ser humano era constituído por quatro humores fundamentais, que seriam a biles preta (melancolia), a biles amarela (cólera), a fleuma e o sangue $^{25}$, sendo fonte de inspiração para Vieira ${ }^{26}$. Se quatro eram os humores, não por acaso também eram quatro os remédios apresentados por Antônio Vieira para a "doença amor".

Influenciado por essa teoria médica, Vieira afirmava que "os remédios do amor, são os contrários do amor, seus motivos de cura" e que "a natureza e a arte curam contrários com contrários" (VIEIRA, 2011, p. 43,71). Se para os cristãos, as doenças eram interpretadas como castigo ou provação divina (POLETTO, 2011, p. 24), exigindo reparação e demonstrações de fé, os contrários pareciam ser "remédios" bastante eficientes para a cura das doenças da alma, tal como a alegria para curar a tristeza, a fé para curar a dúvida, o perdão para curar a ofensa e o amor para curar o ódio.

25 Há, ainda, outra correspondência que pode ser feita entre a teoria humoralista e o Sermão do Mandato do padre Vieira: na teoria hipocrático-galênica, o excesso de água correspondia ao humor fleumático e o excesso de sangue ao humor sanguíneo (MASSIMI, 2009); no sermão, Vieira estabelece uma relação entre a água e o sangue para expressar a ingratidão humana que teria levado Jesus à morte: "a mesma água e o mesmo sangue lhe chegassem ao coração, e se conservassem nele até a morte" (VIEIRA, 2011, p. 51).

26 Paulo Carvalho da Silva analisou as referências que o padre Vieira faz ao sistema hipocrático-galênico ao pregar sobre os remédios que deveriam ser empregados para combater a tristeza, um estado associado à melancolia: "os chamados fleumáticos, de qualidade fria e úmida, seriam naturalmente preguiçosos e insensíveis; os sanguíneos, de corpo quente e úmido, seriam serenos e tranquilos; os coléricos, quentes e secos, mostrar-se-iam destemidos e irascíveis; já os melancólicos, frios e secos, apresentariam um comportamento marcado pela tristeza e temor" (SILVA, 2006, p. 536). 
Ao apresentar Cristo como um enfermo, como alguém fragilizado por uma enfermidade da alma causada pelo amor, Vieira, mais do que promover uma possível identificação, pretendia proporcionar consolo aos enfermos que o ouviam pregar no hospital. Num tempo em que a assepsia era desconhecida, em que doenças, caso não fossem tratadas adequadamente, se alastravam com facilidade (LEAL; FERREIRA, 2007, p. 97), o sermão vieirino difundia a ideia de que o amor de Cristo - por ser incurável - era contagioso e a razão de todas as doenças. Por outro lado, ao anunciar que a cura podia se dar através de "remédios" como o tempo, ausência, ingratidão e "melhorar [sic]do objeto", Vieira estava, também, oferecendo consolo e esperança àqueles que padeciam de doenças do corpo e se encontravam internados no hospital.

Os quatro "remédios" destacados por Vieira têm relação também com a chamada Medicina da Alma, que na época moderna, buscou controlar os diversos distúrbios humanos emocionais e sensitivos, definidos como paixões. A Medicina da Alma, por sua vez, segundo Marina Massimi (2009), tem sua origem no pensamento médico e filosófico grego ${ }^{27}$ e em sua base na "teoria humoralista", baseada nos quatro humores, como já destacado.

Num período em que era muito comum o reconhecimento social - e médico - dos transtornos causados por "doenças da alma", todas elas com efeitos negativos para o corpo humano, bem como as reflexões sobre possíveis tratamentos, cuidados e agentes de cura, o engenhoso Vieira propunha o oposto: a doença que todos deviam possuir e evitar sua cura, a doença de efeitos saudáveis era a doença do amor. Se passageiros eram os sofrimentos do amor, também provisórias eram as aflições do corpo, pois tão logo houvesse reconhecimento da culpa e arrependimento dos pecados, os enfermos conheceriam a salvação da sua alma eternamente. Para tanto - sob a perspectiva da conversão - bastava seguir as recomendações e o exemplo de Cristo que, com alegria, sofreu em vida por amor aos homens e a Deus (BOSI, 2011, p. 4).

Concomitantemente às teorias médicas que divulgavam estudos sobre o corpo e sobre o espírito e propunham procedimentos terapêuticos de cura, circulavam também pela Europa muitos escritos sobre o amor. Mas sobre qual amor se falava e se escrevia no século XVII? Quais foram os poetas, escritores, teólogos e filósofos que, ao refletirem sobre o amor, exerceram influência sobre Vieira e sobre as representações vieirinas do amor? Este será o tema que trataremos no próximo tópico.

27 Consolidada pelo médico grego Hipócrates, pelo médico romano Galeno e pelos filósofos Cícero e Sêneca, firmada na Europa, ao longo da Idade Média, e ampliada na Renascença, a Medicina da Alma baseava-se "numa analogia entre a alma e o corpo", pressupondo "a existência de 'enfermidades da alma", ou seja, admitia "a especificidade da patologia psicológica, ao mesmo tempo em que a dimensão psicológica era tida como intermediária entre a orgânica e a espiritual" (MASSIMI, 2009). 


\section{Sobre esta matéria escreveu eruditamente: o amor nos tempos de Vieira}

O amor, abordado desde a Antiguidade clássica por filósofos e pensadores, esteve especialmente presente no discurso cristão-católico moderno. No século XVII, a difusão da imprensa e as sociabilidades próprias da vida urbana facilitaram a produção e circulação de textos, muitos dos quais versavam sobre este sentimento, tanto sob a forma de poesias, romances e cantigas, quanto sob a forma de sermões, manuais de devoção e tratados teológico-morais. Neste mesmo período, o amor também assumiu uma função política, pois o Estado absolutista pressupunha que entre o governante - o rei - e seus súditos deveria existir um vínculo amoroso e cristão, fundamental para legitimar o poder absoluto dos reis. ${ }^{28}$ Os reis deveriam ser capazes de governar "como um iniciado nos segredos do universo" e com virtudes suficientes para "guiar o povo aos bons modos, na crença e no amor de Deus" (MONTEIRO, 2007, p. 145).

Além do uso político do amor, também estavam disseminadas as discussões promovidas por letrados, membros de sociedades literárias, para quem os tempos modernos haviam herdado de Platão a convicção de que no amor vivia-se algo de misterioso, para lá do afetivo (SIMMEL, 1993, p. 157). Na Itália, por exemplo, academias literárias discutiam diálogos de Platão e promoviam conferências sobre a filosofia do amor e o amor platônico (MONTEIRO, 2007, p. 145). Já na Inglaterra, segundo Alan Macfarlane (1990, p. 191) “a necessidade e a presença do amor transpareciam em boa parte da literatura popular, tanto secular, quanto religiosa, do final do século XVI e começo do XVII". O amor aparecia com sua "natureza irresistível": "As paixões do amor são tão arrebatadoras que subjugam seja o que for, ou conquistando ou matando. [...] O amor é uma doce gota (a doença). É um espinho que fere o coração com incessante prazer".

Luis de Camões (1524-1580), um dos maiores expoentes da literatura portuguesa do século XVI, também se dedicou a refletir sobre o amor, como se constata no soneto "Amor é fogo que arde sem se ver", inspirado nas Sagradas Escrituras, que parece ter inspirado o Sermão do Mandato de 1643, como se constata na estrofe que reforça a ideia da contrariedade do amor:

Mas como causar pode o seu favor

Nos mortais corações conformidade,

Sendo a si tão contrário o mesmo amor? (MARTINS, 1994, p. 4)

280 próprio Vieira, no Sermão dos Bons Anos, de 1641, declarava essa relação de amor entre rei e súditos, ao destacar que os portugueses "souberam amar, e com muita ventura" ao buscar o rei morto. "Portugal, sempre amante de seus reinos, insistia ao sepulcro de el-rei D. Sebastião, chorando e suspirando por ele” (CASTRO; MENDES, 2007, p. 29) 
Enquanto os escritos religiosos dos séculos $\mathrm{XVI}^{29}$ e XVII destacavam o amor união, o amor comunhão, o amor de Deus, o amor fruto da virtude, da pureza, da suavidade, o amor não-passional, moralmente controlado (FLECK; DILLMANN, 2013), a literatura barroca do século XVII enfatizava as controvérsias do amor-paixão, as dualidades beleza/feiúra, verdade/aparência e também o efêmero dessa emoção, o sentido passageiro dos sentimentos (SANTOS, 2006, p. 194). Na obra Pastor Peregrino, escrita por Francisco Rodrigues Lobo e editada em $1608,{ }^{30}$ o leitor tinha acesso a essas "controvérsias", através dos debates sobre os efeitos da beleza sobre o amor $^{31}$.

No século XVII, também circularam na Europa Ocidental, discursos que vinculavam o amor ao prazer sexual, a uma forma de amor ilícito, que resultava do excesso de luxúria que, ao ser encarado como enfermidade, implicava na proposição de formas de cura. A chamada "febre amorosa" poderia apresentar inúmeros sintomas como "batimentos do coração, inchamento do rosto, apetites depravados, tristeza, suspiros, lágrimas sem motivo, fome insaciável, sede raivosa [...] epilepsia, raivas, furores uterinos", que não seriam curados a não ser pelos "remédios do amor." (FERRAND, 1623, p. 264 apud PRIORE, 2001, p. 104). Nesta perspectiva, o amor era percebido tanto como causa, quanto como remédio, cabendo ao "enfermo de amor" a busca pela cura junto ao "médico sacerdote", que lhe receitaria os sete melhores remédios, os sacramentos (PRIORE, 2001, p. 104-105).

Muitos filósofos e teólogos doutores da Igreja também escreveram sobre o amor na época moderna, retratando-o como uma propriedade natural dos homens e como um sentimento que pautava tanto a relação dos homens consigo mesmos, quanto a comunicação com a divindade e com o próximo, podendo ter exercido certa influência sobre o pensamento de Vieira. (CARDIM, 1999, p. 24) Sem a intenção de especular e cotejar estilos de escrita/linguagem e/ou concepções de amor expressas no pensamento de Vieira sobre este sentimento, destacaremos, na continuidade, os autores referidos diretamente pelo padre Vieira no Sermão do Mandato de 1643.

29 Em relação aos textos religiosos produzidos no século XVI, vale destacar as reflexões contidas nos Exercícios Espirituais redigidos por Inácio de Loyola, o fundador da Companhia de Jesus, a ordem religiosa na qual Antônio Vieira ingressou no ano de 1623. Uma dessas reflexões primordiais buscava estabelecer a ordem na vida cristã, "através das meditações sobre o amor de Deus [para] transformar a vida em conformidade com o Evangelho" (FLECK, 1999, p. 102). As "meditações sobre o Amor de Deus" de Loyola, mais do que reforçar imagens cristãs sobre o inferno, recomendavam meditações, auxiliando os fiéis a reavaliarem suas atitudes, sentimentos e valores (FLECK, 1999, p. 102).

$30 \mathrm{Na}$ obra Pastor Peregrino (1608), Francisco Rodrigues Lobo destacava a necessidade do amor humano resistente ao tempo e à sujeição da beleza, dizendo que "se ama tudo o que se deseja, e que mais perfeito será o que se emprega em cousas altas e mais isentas da jurisdição do tempo e da forma, porque amar bens e gostos da sorte é interesse do apetite, amar beleza e perfeições do rosto é amor sujeito às mudanças dele, amar partes da alma e do juízo é verdadeiro amor firme e levantado" (LOBO, 1608, p. 164 apud SANTOS, 2006, p. 195).

31 Interessante destacar os argumentos que belas e feias empregavam para justificar a importância da beleza para o cultivo do amor. Para as feias, "o amor não é eleição, antes acerto, e por isso os que o fizeram deus o pintaram cego, e dito é comum que quem feia ama formosa lhe parece”. Já para as belas, "outra coisa ouvi eu dizer dessa pintura, isto é do amor cego, e era que havia de escolher com os olhos abertos e amar com eles cerrados” (SANTOS, 2006, p. 194). 


\section{Deixo às autoridades, porque são sabidas: autores e obras de referência para Vieira}

No sermão do mandato de 1643 predominam as referências aos escritos antigos e medievais - característica da literatura cristã do período moderno e presente em outros sermões de Vieira ${ }^{32}$-, tais como os de Ovídio, Cícero, Santo Agostinho e São Tomás de Aquino $^{33}$, para citar apenas alguns. ${ }^{34}$

$\mathrm{Na}$ apresentação e justificativa do sermão, Vieira destaca a impossibilidade de mostrar a morte de Jesus por "amor", por um "amor sem remédio", sem antes refletir sobre quais seriam esses "remédios do amor". Desse modo, evoca Ovídio (43 a.C. - 17 d.C.), um clássico poeta romano, dedicado à retórica e ao latim, a quem ele se referia como "galeno do amor humano", que escreveu, entre outras poesias, O remédio do amor [De Remedio Amoris], obra que foi uma das principais inspirações de Vieira para este sermão, no qual procura analisar a eficácia dos tais "remédios" 35 .

O filósofo grego Orígines (185 d.C. - 253 d.C.), autor de extensa obra cristã e de inúmeros comentários bíblicos foi, para Vieira, um homem de "notável pensamento", auxiliando o jesuíta na reflexão sobre os efeitos da "ausência" para o amor, tal qual o sentido por Madalena, que temia que a ausência esfriasse o seu amor por Cristo (VIEIRA, 2011, p. 29).

Para as interpretações bíblicas, principalmente dos Evangelhos de João, de Paulo e de Mateus, Vieira buscava apoio nos "doutores da Igreja", geralmente, teólogos e filósofos canonizados pela Igreja Católica, como o italiano Santo Anselmo (1034-1109), autor de Por que Deus se tornou Homem?, a quem Vieira elogiava por comentar "excelentemente" passagens dos evangelhos (VIEIRA, 2011, p. 24). Outro "doutor da Igreja", muito respeitado e consultado pelos religiosos da Companhia de Jesus foi São Bernardo (1090-1153) que, segundo Jacques de Voragine, na sua Legenda Áurea, ganhou "fama" em vida e "o mundo todo" desejava "exaltá-lo" (VARAZZE, 2003, p. 688). Vieira o citou, por exemplo, para reforçar a ideia de que Cristo não deixava de amar "em nenhum lugar ou distância, porque [seu sentimento, verdadeiramente] é amor" (VIEIRA, 2011, p. 30). Outro doutor citado por Vieira

32 De acordo com a tradição humanista aristotélica, apropriada pela Companhia de Jesus, as virtudes morais surgem pelos hábitos: “[...] tornamo-nos justos praticando atos justos, e assim com a temperança, a bravura [...].” Aristóteles (1987, p. 27).

33 Em outros Sermões do Mandato, Vieira se valeu também de Xenofonte, Cassiodoro, Tito Lívio, Quinto Lúrcio, Sêneca, Plutarco, Severino Boécio, São Jerônimo, São João Crisóstomo, Papa São Gregório, São Bernardo, o que nos leva, mais uma vez, a ponderar sobre o nível de instrução dos ouvintes e da apreensão da mensagem dos sermões que pregava. Ver Maziero (2004, p. 3-4).

34 Para João Carlos de Carvalho, a originalidade de Vieira estava na forma como articulava e distribuía autores gregos e latinos em seus sermões, já que as interpretações por ele referidas eram conhecidas pela parcela culta da sociedade da época, não sendo empregadas para serem "aprofundadas ou discutidas filosoficamente, mas para servirem de argumento ou de confirmação ao discurso" (CARVALHO, 2005, p. 152).

35 Cabe destacar, também, que, no século XV, o humanista Eneas Silvio Piccolomini - posteriormente Papa Pio II escreveu a obra Remédio de amor. Sobre o discurso misógino contido nesta obra, ver análise realizada por Martins (2011, p. 38). 
foi São Cirilo Jerosolimitano ${ }^{36}$ [de Jerusalém] (315-387), que o auxiliaria a refletir sobre a ingratidão (VIEIRA, 2011, p. 51).

Ao referir-se a Santo Agostinho, São Crisóstomo e Tertuliano, Vieira os chamava de "autoridades [...] sabidas". A "sutileza" de Santo Agostinho e sua obra Confissões foram uma referência permanente para o pregador (VIEIRA, 2011, p. 51, 64), assim como a Suma Teológica ${ }^{37}$ do dominicano São Tomás de Aquino (1228-1274), um dos muitos teólogos que "reafirmaram o caráter natural do amor, encarando esse afeto como uma inclinação natural para o bem" (CARDIM, 1999, p. 26) e definiram o amor como o princípio de um movimento tendente para o fim amado (CARVALHO, 2005, p. 479; SILVA, 2008, p. 479). É inegável a influência exercida por esse teólogo sobre Vieira e, especialmente, na escrita do Sermão do Mandato de 1643, pregado exatamente 80 anos após a conclusão do Concílio de Trento pelo Papa Pio IV, um período de intensa propagação de obras morais inspiradas na autoridade de Tomás de Aquino.

Mesmo no século XVIII, os argumentos teológicos mantinham-se presentes na definição de "amor", como que se pode constatar no Vocabulário Portuguez e Latino, organizado pelo padre Raphael de Bluteau (1712-1728, p. 453), que define que "desde o trono de Deus até a mais ínfima criatura, tudo no mundo é amor". Também outros dicionários setecentistas, como o Dicionário da Língua Portuguesa, publicado pela Academia Real das Ciências de Lisboa, em 1793, recorreram aos escritos de Vieira para melhor definirem o que era $\operatorname{amor}^{38}$. As representações do amor presentes no Sermão do Mandato de 1643 são o tema o próximo tópico.

36 São Cirilo foi autor das Catequeses Mistagógicas, que tratam da iniciação aos sacramentos e revelam "os ritos da iniciação cristã na Igreja jerosolimitana do século IV e a teologia que lhe subjaz" (PACHECO, 2010, p. 170).

37 A Suma Teológica se divide em três partes, designadas por algarismos romanos. Cada parte é dividida em questões e cada questão, em artigo. A estrutura dos artigos comporta a seguinte sequência: pergunta; argumentos a favor de uma resposta possível; argumentos contrários a esta resposta; corpo do artigo, resposta, sentença ou determinação; respostas aos argumentos iniciais. A opinião do autor encontra-se no corpo do artigo, nas respostas aos argumentos iniciais e, às vezes, nos argumentos em sentido contrário (NASCIMENTO, 2008, p. 93).

38 O Dicionário da Língua portuguesa, publicado pela Academia Real das Ciências de Lisboa, em 1793, trazia muitas locuções adverbiais de intensidade a partir do verbo "amar", tal como utilizado por Vieira, citando-o, inclusive, e demonstrando, assim, o quanto a escrita vieirina influenciou a língua portuguesa. "Amar" viria acompanhado de: com a mesma vida, com a própria alma, com o lume dos olhos, com toda a alma, com todas as forças, com todo o coração, constantemente, constantissimamente, cordialmente, da alma, das entranhas do coração, de amor puro e sincero, de coração, de uma singular afeição, delicadamente, de perfeito coração, desonestamente, desinteressadamente, desordenadamente, de toda a alma, de todas as forças, de todo o coração, de todo o entendimento, deveras, de verdade, dissimuladamente, docemente, do coração, do intimo da alma, do peito, eficazmente, em extremo, em grão maneira, em particular, em sua alma, em vão, encarecidamente, enternecidamente, erradamente, especialmente, espiritualmente, estranhamente, estreitamente, excelentemente, extraordinariamente, extremadamente, extremosamente, falsamente, ferventemente, ferventissimamente, fervorosamente, fidelissimamente, fielmente, finamente, fingidamente, fora da medida dos outros, fortemente, friamente, graciosamente, grandemente, grandissimamente, gratuitamente, heroicamente, humanamente, humildosamente, infinitamente, intensamente, intensissimamente, intimamente, lealmene, liberalmente, limpamente, loucamente, mais que a si, muito, na sua alma, nas entranhas, naturalmente, ordenadamente, paternalmente, perdidamente, perfeitamente, perfeitissimamente, por extremo, primorosamente, prudentemente, puramente, reciprocamente, remissamente, sabiamente, saborosamente, sem limite, sem medida, sem respeito de premio, sem termo, sensualmente, singularissimamente, singularmente, sobejamente, sobre maneira, sobremodo, sobre todas as cousas, sobre todo o amor, sobre todo o encarecimento, suavemente, sumamente, temerariamente, tenramente, ternissimamente, tibiamente, torpemente, valentemente, verdadeiramente, unicamente. 


\section{Não há amor tão robusto que chegue a ser velho: sentidos $e$ representações do amor em Vieira}

No Evangelho de João (13:1), lemos: "Sabendo Jesus que chegara a sua hora de passar deste mundo para o Pai, Ele que amara os seus que estavam no mundo, levou até ao fim o seu amor por eles". Inspirado nessa passagem bíblica, Vieira declara: "Diz o vosso evangelista [referindo-se ao apóstolo S. João] que a enfermidade vos trouxe a este lugar", "qual seja esta enfermidade [...] diz que é de amor, e de amor nosso, e de amor incurável" (VIEIRA, 2011, p. 9).

É a partir da reflexão que Vieira faz sobre os "remédios do amor" que podemos identificar as representações que o pregador jesuíta constrói sobre o amor. Em primeiro lugar, para Vieira, o amor era a "união de vontades" (VIEIRA, 2011, p. 30), a enfermidade da alma, o sentimento intenso, que faz chorar e a luz que resplandece. Já o "perfeito amor" era aquele que se alegrava perante a partida do ser amado para melhorar de estado (para se tornar um amor ainda maior) e que não se entristecia em função da ausência. Para ilustrar, o jesuíta recorre à passagem bíblica que descreve o episódio em que Jesus, ao se despedir de seus apóstolos, pede que não se entristeçam diante do anúncio de sua partida da terra, lembrando-os de que se o amassem verdadeiramente deveriam saber "que o Padre para onde vou é maior que eu" (VIEIRA, 2011, p. 60)

E sendo a minha partida para melhorar tanto de estado e de objeto, se eles me amaram verdadeira e desinteressadamente, haviam de poder mais as minhas melhoras para os alegrar, que a minha ausência para os entristecer. Assim é em lei do perfeito amor (VIEIRA, 2011, p. 61)

Se nem todos os amores eram iguais ${ }^{39}$ e nem todos se encontravam enfermos da mesma doença e com a mesma gravidade, ${ }^{40}$ havia sempre a possibilidade de existir um "amor maior" e mais intenso. Em duas passagens, Vieira identifica os diferentes tipos de manifestação deste sentimento, que avaliava como mais ou menos intenso: "Dizem que um amor com outro se paga, e mais certo, é que um amor com outro se apaga" e "no mesmo coração não podem caber dois amores, porque o amor que não é intenso não é amor" (VIEIRA, 2011, p. 55-56).

Uma vez que o amor possuía diferentes medidas e intensidades, Vieira atribuía várias qualificações/adjetivações ao verbo "amar", tais como "finamente", "fielmente",

39 A Filosofia do amor destaca os diversos amores: amor a Deus, amor à pátria, amor cristão ao próximo, etc. (SIMMEL, 1993, p. 120).

40 Vale lembrar, como já foi destacado, que durante o século XVI e o XVII, a população de Lisboa era assolada por inúmeras doenças e epidemias. 
"intensamente" ou "alegremente". O amor, por sua vez, poderia ser fino, fiel, intenso e alegre, um tipo ideal de amor que deveria ser cultivado, por ser a expressão mais nobre dos corações humanos, tal como o "amor menino", considerado singelo, puro, inocente, doce e sem máculas.

No século XVII, as interpretações de Vieira sobre o amor como índole moral eram compartilhadas por vários contemporâneos seus, dentre os quais se destacam alguns prestigiados autores da literatura portuguesa, que refletiram sobre o amor com diferentes abordagens, como Manuel de Faria e Sousa, autor de Epitome de las Historias portuguesas (1628), Martim Afonso de Melo, autor de Escritorio Avarento (1655) Francisco Manuel de Melo, autor de Carta de Guia de Casados (1651), Manuel Monteiro de Campos, autor de Academia nos Montes e Conversações de Homens Nobres (1642), Francisco Rodrigues Lobo, autor de Corte na Aldeia e noites de inverno (1619), Manuel Severim de Faria, autor de Exercícios de perfeição e doutrina espiritual para extinguir e adquirir virtudes (1643), Frei Antônio das Chagas, autor de Faíscas de Amor Divino (1683), Frei Cristóvão Godinho, autor de Poderes do Amor em geral e oras de conversação particular (1657), e Frei Francisco de Santo Agostinho de Macedo, tradutor de Os Lusíadas para o latim (CARDIM, 1999, p. 32).

Constata-se, portanto, que as representações do amor presentes nos sermões de Vieira se inserem plenamente no contexto teológico e literário do século XVII português, o que, contudo, não elimina o caráter inovador e inédito das mensagens que pregava a diferentes públicos, em Portugal ou na América portuguesa. Em 1643, pregando aos doentes do Hospital Real de Lisboa, Vieira destacará dois tipos fundamentais de amor, completares e, ao mesmo tempo, distintos: o amor humano e o amor divino.

\section{Vamos acreditando [no] amor e desacreditando [nos] remédios: o amor humano e o amor divino}

No Sermão do Mandato, de 1643, Vieira tratará do amor humano e do amor divino, ao abordar os "remédios do amor" e ao questionar sobre a própria natureza do amor: o que é, afinal, esse afeto que deve ser curado e que pode curar? Vieira chama o amor humano de fraco, inconstante e imperfeito: "O amor, a quem remediou, e pôde curar o tempo, nem poderá ser que fosse doença; mas não é amor” (SILVA, 2008, p. 477; VIEIRA, 2011, p. 16).

Nele, Vieira não só propõe um receituário para os males do amor, como define o amor humano como frágil, por aproximar-se mais da dor do que do prazer, sendo, por isso, "um amor que não é amor, um mal a ser remediado, uma dor da alma" (SILVA, 2008, p. 477), enquanto o amor a Deus deveria ser fiel e eterno, cultivado permanentemente. Vieira ressalta a fragilidade dos sentimentos humanos, dos "corações de cera" incapazes de resistir 
ao tempo, ao "atrevido" tempo, que "tudo faz esquecer", caracterizando o amor humano como fraco, inconstante, grosseiro, imperfeito, cego, desatinado, perdido, governado por apetites, (VIEIRA, 2011, p. 16, 73). Para o pregador jesuíta, a fragilidade e fraqueza não resistiriam aos sensíveis efeitos dos "remédios" indicados, que ao serem adotados, produziriam efeitos rápidos, diminuindo ou acabando com o sentimento de amor humano.

O "tempo" era um dos fortes remédios contra o amor, contra o mal do amor, contra a doença amor, e o primeiro na ordem de enumeração. Apresentado como muito eficaz no combate ao amor humano, cabia ao "tempo" demonstrar que "Não há amor tão robusto que chegue a ser velho" e desarmar o amor, enfraquecê-lo, afrouxá-lo, embotá-lo, pois "faz-lhe crescer as asas, com que voa e foge" (VIEIRA, 2011, p. 13). A força do tempo estava na potencialidade das mudanças e nos desgastes promovidos no amor humano, já que "o tempo tira a novidade às coisas, descobre-lhe os defeitos, enfastia-lhe o gosto" e se gasta: "gasta-se o ferro com o uso, quanto mais o amor!" (VIEIRA, 2011, p.13-14).

Além de sublinhar a ação corrosiva e desgastante do tempo sobre o amor, de um tempo que acabava com "todas as coisas humanas" e que "tudo gasta, tudo digere", até mesmo a memória (VIEIRA, 2011, p. 19), o pregador também insiste em caracterizar os "fervores da afeição" como absolutamente temporários e o amor humano como mais mortal do que as enfermidades do corpo, pois era falho e pecaminoso. A própria menção ao "corpo" enquanto fonte de pecados - já aponta para a interpretação da Igreja moderna póstridentina que reforçava sua doutrina, defendendo a exemplaridade das vidas santas, enfatizando a eliminação de pecados capitais e condenando os sentimentos amorosos por sua vinculação aos prazeres carnais e à luxúria. A fraqueza humana advinda das tentações da carne era uma imperfeição a ser combatida com oração, penitência, lembrança da morte e dos tormentos do inferno (PRIORE, 2001, p. 105).

Dentre os remédios mais eficazes contra o doente de amor - seu maior contrário estava a ingratidão, pois transformava o amor em aborrecimento, eliminava seu motivo [o motivo de amar], combatendo-o "pelo entendimento e pela vontade", ferindo "no coração". Mesmo o mais bem fundado amor podia ser transformado em aborrecimento, dado o poder da ingratidão de parte dos pecadores. O amor humano era, em si, agravante, injusto, sacrílego, irado e ingrato, pois com ingratidão e "fereza", os homens teriam pagado ao Cristo morto, "mas morto pela salvação dos mesmos homens" (VIEIRA, 2011, p. 53). No argumento de Vieira, aqueles que haviam convivido com Jesus - os apóstolos - haviam retribuído o amor com abandono, com negação e crucificação, ou seja, teriam sido ingratos (VIEIRA, 2011, p. 41-44).

Para Vieira, o amor humano também não resistiria à ausência, representada pela distância entre os seres no espaço, que faria "cair [o amor] no esquecimento", visto que a "consequência ordinária" do afastamento é "ir-se o amor quando se vai o amante" (VIEIRA, 2011, p. 34). Também a morte apartaria pela ausência, faria esquecer e esfriar o amor, pois 
mesmo o mais qualificado amor humano não resistiria aos "poderes da ausência" (VIEIRA, 2011, p. 29). A própria sepultura dos mortos podia ser chamada de "terra do esquecimento", já que "os mortos são tão esquecidos", mesmo havendo "tão pouca terra entre eles e os vivos". Diante da morte, as "últimas respirações do amor" se manifestariam nos suspiros, nas lágrimas e no palpitar da saudade (VIEIRA, 2011, p. 27). O coração [amor] humano "se aquenta pelos olhos", através da visão, uma vez que são "os olhos as frestas do coração" e o coração estando ausente, o amor estaria também ausente. Longe dos olhos, "recolhe dentro de si toda a força e ímpeto do amor" (VIEIRA, 2011, p. 29, 36) e acabaria por rebentar, atingindo até mesmo os "corações mais finos".

De todo modo, Vieira pretendia reforçar um determinado sentimento de amor entre os homens e dos homens em relação a Deus. No período moderno, era forte entre os fiéis o impacto do discurso cristão sobre a necessidade do amor e de todos os outros atributos a ele ligados, como a fidelidade, a amizade, a confiança, a partilha material, a memória e a gratidão para a entrega total da alma a Deus e ao seu amor. ${ }^{41}$ Era, justamente, essa "lembrança do amor de Deus que impelia as pessoas a amarem o próximo", pois dessa forma, estariam amando "a sua própria perfeição e a pessoa divina." (CARDIM, 1999, p. 25).

Assim, entende-se a importância que Vieira atribui ao amor divino - distinto do amor humano -, o "amor verdadeiro" porque amor de Cristo, perfeitíssimo e incurável, um amor sem remédio, um fogo que não se apaga (VIEIRA, 2011, p. 35) e que provém de Deus "Padre". Ao final do sermão, Vieira destacou que "com os remédios cresce a enfermidade, e com os contrários se aumenta" (VIEIRA, 2011, p. 55). Este seria o caso do amor de Jesus Cristo, dono de um coração "humano e divino", que não esfriava e não se dividia, ao contrário, era forte o suficiente para ser o remédio das "loucuras" do amor humano (VIEIRA, 2011, p. 30, 36, 73). Ao refletir sobre esse amor de Cristo e "buscando a causa destes contrários efeitos [...] e filosofando sobre a diferença deles", Vieira concluiu "que procedia da qualidade singular do coração de Cristo", um coração com qualidade soberana (VIEIRA, 2011, p. 49, 52). Perante todo e qualquer grande amor humano, o amor divino se destacaria, dado o seu caráter "tão digno" e tão maior. E, diante do amor de Cristo qualquer formosura humana tornava-se fealdade e qualquer grandeza tornava-se vileza.

Questionando-se sobre a existência do verdadeiro amor, Vieira pergunta "onde se achará?" e anunciava a resposta: "Só em Vós, Fênix Divino, Só em Vós". Só a perfeição do amor divino "mereceu o nome de amor", pois "vive imortal" e não diminui e nem enfraquece. Esse amor "tem obrigação de ser eterno", senão, "nunca foi amor" (VIEIRA, 2011,

41 Duas situações registradas nas Cartas Ânuas da Província Jesuítica do Paraguai do século XVIII confirmam esta total entrega a Deus por religiosos da Companhia de Jesus. Numa delas, um jesuíta, em seu leito de morte, "rogó a Dios que le alargase un poco la vida, para poder sufrir más por su amor". A outra se encontra no obituário do Padre Blas Riechinger registrado pelo padre relator da Ânua: "Consumióle, parece el amor a Jesús. Pues, en la fiesta del Santo Nombre de Jesús nuestro Padre Blas, que sufrió un ataque cardíaco, por la vehemencia de su amor, la cual le causó su última enfermedad y su temprana muerte." (C. A. 1750-1756, 1927, p. 133, apud CERVEIRA, 2008, p. 124). 
p.17). Cristo, o "divino amante dos homens", 42 devotou à Humanidade um amor que não se altera, não muda a sua natureza, é eterno, é simplesmente amor (VIEIRA, 2011, p. 30), um amor "estimação" (VIEIRA, 2011., p. 38):

\begin{abstract}
Não só vos rogo, Pai meu, por estes poucos discípulos que tenho presentes, senão por todos aqueles que, por meio da sua doutrina, hão de crer em mim - que são todos os cristãos -, e o que vos peço é que, assim como nós, por união de amor, somos uma mesma coisa, Vós em mim e eu em Vós, assim eles em Vós e em mim sejam também uma coisa, pela mesma união(VIEIRA, 2011, p. 67-68, grifos nossos)
\end{abstract}

Vieira enfatizava, assim, o princípio de amor existente nos homens pelo fato de serem eles, em si, a união com o divino. Mas essa "união de amor" não era efeito natural da manifestação divina em todos os homens, e, sim, somente naqueles que eram cristãos e observavam a doutrina da Igreja Católica. Santo Agostinho já destacava a necessidade de os homens ligarem-se ao amor de Deus para a permanência na eternidade: "Ligai-vos o mais possível ao amor a Deus para que, do mesmo modo que Deus é eterno, também vós permanecereis eternos, pois tal é o objetivo do amor e tal é quem ama" (Apud ARENDT, 1997, p. 29).

Para o pregador jesuíta, o amor de Cristo chegaria aos homens por meio do "Espírito Santo", um amor "não menos intenso, não menos ardente, não menos abrasado que em forma de fogo" (VIEIRA, 2011, p. 32, 35), como o próprio Cristo advertiu aos seus discípulos: "Vim lançar fogo sobre a terra e que quero eu, senão que ele se acenda?"43

Se eu me for, se eu me ausentar de vós, então vos mandarei o fogo do meu amor, ou o meu amor em fogo, para que vejais quanto vos convém esta minha ausência e para que não receeis que ela, como costuma, me haja de esfriar o amor, porque antes o há de entender e acender mais (VIEIRA, 2011, p. 35-36)

O amor que Cristo sentia pelos homens era divino, alto, supremo, excedendo a toda imaginação humana, fazendo-se sentir, inclusive, entre os pecadores: "[...] eu estou neles, e tu estás em mim, para que eles sejam consumados na unidade" (VIEIRA, 2011, p. 68-69) Cristo, unido ao amor do "Pai", o amor de Deus, melhorou o objeto e, assim, amou mais e

42 Duby (1989, p. 34) ressalta que a partir do século XII, ao menos na França, circulavam mensagens em cartas e biografias de mulheres santas que, assim como os sermões, eram largamente difundidas, com a intenção de corrigir condutas, demonstrar exemplos de virtudes e conservar - especialmente nas mulheres - o sentimento de amor a Deus, o "esposo celeste".

43 Lucas (12, p.49), Vieira (2011, p. 35). 
muito mais os homens (VIEIRA, 2011, p. 70). Um amor maior, de grande imensidade, com intensos afetos, luminoso e "brilhante como o sol", que mesmo "no Céu", "distante" dos homens, irradiava a todos da mesma forma com eficazes efeitos (VIEIRA, 2011, p. 38-39).

Se o amor era luz, o amor de Cristo era "a verdadeira luz", "a saúde das almas", capaz de perdoar golpes como a traição e a negação, tal como contam os Evangelhos, ao destacar que Judas "o vendeu" e Pedro "o negou" (VIEIRA, 2011, p. 10, 46, 56). O amor "verdadeiramente divino", "verdadeiramente imenso", "fino" e singular teria se expressado na atitude humilde que Cristo teve "ao lavar seus pés "por suas próprias mãos" dos "infiéis", "traidores", "covardes" e "desleais". Assim, o amor de Cristo, "das maiores ingratidões faz motivos de mais amar" e "de mais bem fazer", não se limitando a amar apenas os que "estavam no mundo, senão também aos que não estavam", pois seu amor era benéfico, benigno e misericordioso (VIEIRA, 2011, p. 44-54). Se Cristo morreu de amor pelos homens, os homens deveriam viver para sofrer por seu amor, justificando, dessa forma, os sofrimentos experimentados pelos doentes hospitalizados, a quem Vieira pregava o Sermão do Mandato.

De acordo com o jesuíta, o que diferenciava o amor humano do amor de Cristo era a intensidade do amor, muito maior em Cristo, pois era "amorosíssimo" e de grande "firmeza" (VIEIRA, 2011, p. 60-62). Dono de um "amor só constante", de um "amor só amor", Cristo carregava consigo o "relógio do amor no peito" (VIEIRA, 2011, p. 20). Se o Paraíso era o destino das almas santas e amorosas, a Terra era o "refúgio da pobreza" e somente o amor de Cristo - o "amor sem remédio" - podia promover a "a saúde de nossas almas" e servir de modelo aos pecadores.

O Hospital Real de Lisboa, cenário da pregação deste sermão, mais do que um "refúgio da pobreza" - marcado pela indigência, pelas doenças e pela morte que castigavam, indistintamente, tanto os corpos dos nobres, quanto os dos pobres portugueses - parece ter sido, para Vieira, o espaço por excelência do empenho pela cura da alma. Ao questionar-se se "ferido o amor [de Cristo] no cérebro, e ferido no coração, como pode [alguém] viver?" (VIEIRA, 2011, p. 42), Vieira transmite a ideia de que doenças que atingiam o cérebro ou o coração (pode-se entender o órgão) eram as únicas fatais, sendo as demais, passíveis de cura. Por entender que os sofrimentos físicos enfrentados por muitos dos hospitalizados decorriam dos males da alma e da fraqueza amorosa, Vieira procurou consolar os enfermos, dizendo-lhes que estes eram necessários para a depuração e a cura do espírito, logo, fundamentais para a salvação da alma. 


\section{Considerações Finais}

No século XVII, leigos e religiosos acreditavam que as moléstias do corpo eram reflexos da enfermidade da alma, as quais só poderiam ser curadas pela intervenção do amor divino. Essa foi, possivelmente, uma das principais motivações de Vieira para a pregação do seu primeiro Sermão do Mandato, em 1643, no principal hospital da capital portuguesa. Ao longo do sermão se encontram diversas expressões que evidenciam o ambiente, tais como ferido (a), tristeza, dor, chagas, enfermidades e aflição, e o público ao qual se destinava a pregação: "não é muito que viesse a parar em um hospital", "a enfermidade vos trouxe a este lugar", "tão enfermo que a vossa mesma ciência vos promete poucas horas de vida" (VIEIRA, 2011, p. 9) e, ainda, "Vos, Enfermo divino, que estais nos últimos transes da vida" (VIEIRA, 2011, p. 73).

É preciso considerar, como destacamos no início deste artigo, que inúmeras são as possibilidades de apropriação que os ouvintes/leitores podem ter feito deste sermão. Além disso, diversas são as variáveis a ser consideradas quando se pensa no grupo para o qual Vieira pregou, visto que se pode apenas inferir qual era o público internado no hospital naquele momento do ano de 1643 - certamente heterogêneo do ponto de visto social, intelectual, cultural e religioso - exceto em relação a um fator que uniformizava o grupo, a sua condição de doentes.

Nesse sermão destinado aos enfermos, em que ficam evidentes os objetivos contrarreformistas de conversão e convencimento dos ouvintes/leitores quanto às "verdades da fé", Vieira faz questão de reforçar que "tudo o que acabo de dizer é filosofia não minha, senão do mesmo Cristo" (VIEIRA, 2011, p. 37) e - em uma das passagens do sermão instiga os doentes a refletirem sobre a proximidade da morte: "Oh! Quanto nos pesa nesta hora, e para sempre, de vos não ter amado como devíamos!” (VIEIRA, 2011, p. 74). Da mesma forma como nem todos os indivíduos manifestavam as mesmas doenças ou as mesmas deformidades no corpo, nem todos possuíam a mesma forma de amar, havendo uma distinção entre o amor humano e o amor de Cristo, razão pela qual Vieira recorreu a diferentes expressões e de intensidade para definir essas diversas formas e modos de amar.

Para Vieira, os sofrimentos humanos decorrentes das enfermidades do corpo eram, ao mesmo tempo, o expurgo dos pecados da alma e os remédios para a sua cura, devendo ser experimentados com resignação. Se Cristo veio ao mundo com uma "doença incurável", era justo que os homens também experimentassem a enfermidade, na condição de doentes de amor ou doentes do corpo. Os doentes de amor estariam em estágio de perfeição moral e espiritual, uma enfermidade pouco provável aos homens dotados de "frágeis corações de cera", mas não impossível, desde que o amor fosse fino, puro e singelo como o "amor menino". Os motivos das enfermidades do corpo estavam, muitas vezes, relacionados com os estados debilitados da alma. Desse modo, a doença desenvolvida poderia ser justificada pelo fato de os sujeitos não estarem verdadeiramente enfermos de amor, ou estarem 
facilmente suscetíveis à cura com os remédios do amor. Nesse caso, a "doença amor" poderia ser um antídoto eficaz contra doenças do corpo ou, ao menos, uma possibilidade de cura, na vida terrena ou na eternidade. Somente Cristo seria alvo de uma enfermidade sem remédio, mas os homens podiam ser facilmente curados, já que "muitas enfermidades se curam só com a mudança do ar" (VIEIRA, 2011, p. 27), argumento que, com certeza, devia trazer esperança de cura aos doentes internados no Hospital Real ${ }^{44}$.

As reflexões que o sermão deveria provocar e os remédios recomendados por Vieira aos enfermos não deixavam de ser práticas de cura socialmente aceitas, na medida em que havia um pretenso fim terapêutico no atendimento espiritual que os religiosos realizavam em hospitais. Apesar do discurso religioso, sustentado em passagens bíblicas e em autoridades da Igreja, Vieira parece se inspirar em procedimentos terapêuticos próprios da teoria médica hipocrático-galênica, na medida em que propõe o restabelecimento da saúde, através da ação de agentes contrários à causa da enfermidade, como se pode constatar nas doenças de amor, cuja cura residia em remédios como o tempo, a ausência, a ingratidão e a melhora do objeto.

Refletindo sobre esses remédios do amor, o padre Vieira construía suas representações sobre esse sentimento, ao mesmo tempo, humano e divino, e metaforicamente, apresentava também possibilidades de cura para as doenças do corpo, como o tempo, que eliminava o amor, mas também a dor e o sofrimento. Ou a ausência que, devido às longas distâncias, podia curar o doente de amor, ao mesmo tempo em que podia ser importante aliada no tratamento de uma da enfermidade corporal, já que viagens longas e "mudanças de ar" podiam restabelecer a saúde. O sermão, contudo, não descuidava de idealizar o amor, ressaltando a necessidade de o ser humano contaminar-se deste nobre sentimento, nutrir-se dessa afeição sutil, empenhar-se no fervor do seu cultivo, de modo a, efetivamente adoecer, mas de amor!

\section{Referências}

VIEIRA, António. O mandamento do Amor ou O Sermão do Mandato. Lisboa: Largebooks, 2011. (Coleção Earth Gift).

ARENDT, Hannah. O conceito de amor em Santo Agostinho. Lisboa: Instituto Piaget, 1997.

ARISTÓTELES. Ética a Nicômano. São Paulo: Nova Cultural, 1987.

44 Embora Vieira estabeleça uma relação entre cura e enfermidade e que recomende "remédios" para sentimentos humanos, anunciando, em grande medida, seus conhecimentos sobre a medicina da alma, não é possível identificar neste sermão qualquer indício de que tivesse um conhecimento médico ou farmacêutico. 
AZEVEDO, João Lúcio de. História de Antônio Vieira. São Paulo: Alameda, 2008. t. 1.

BAUMAN, Zygmunt. Amor líquido: sobre a fragilidade dos laços humanos. Rio de Janeiro: Jorge Zahar, 2004.

BLUTEAU, Raphael. Vocabulario portuguez \& latino: aulico, anatomico, architectonico. Coimbra: Collegio das Artes da Companhia de Jesu, 1712 - 1728. 8 v.

in http://www.brasiliana.usp.br/dicionario/edicao/1BOSI, Alfredo (Org.). Padre Antônio Vieira - Essencial. São Paulo: Companhia das Letras, 2011. (Coleção Penguin).

CARDIM, Pedro. Amor e amizade na cultura política dos séculos XVI e XVII. Lusitania Sacra, Lisboa, n. 11, p. 21-57, 1999.

CARVALHO, José Carlos de. Uma leitura do texto lágrimas de Heráclito defendidas em Roma pelo padre Antonio Vieira Contra o riso de Demócrito. In: o fio da memória: ensaios. Lisboa: Colibri, 2005. p. 135-152.

CASTRO, Aníbal Pinto de; MENDES, Margarida Vieira. História e antologia da literatura portuguesa, século XVIl. Lisboa: Fundação Calouste Gulbenkian, 2007. n. 37.

CERTEAU, Michel de. A operação histórica. In: LE GOFF, Jacques; NORA, Pierre. Fazer História: novos problemas. Lisboa: Bertrand, 1977. v. 1. p. 17-58.

CERVEIRA, Luís Alexandre. Paixões, transgressões e tragédias: as missões populares urbanas e campestres (Província Jesuítica do Paraguai, primeira metade do século XVIII). 2008. Dissertação (Mestrado em História) - Universidade do Vale do Rio dos Sinos, São Leopoldo, 2008.

CESAR, Thiago Groh de Mello. A política externa de D. João IV e o Padre Antonio Vieira: as negociações com os Países Baixos (1641-1648). 2011. Dissertação (Mestrado em História) Universidade Federal Fluminense, Niterói, 2011.

DUBY, Georges. Idade média, idade dos homens: do amor e outros ensaios. São Paulo: Companhia das Letras, 1989.

ECO, Umberto (Org.). História da beleza. Rio de Janeiro: Record, 2010.

FLECK, Eliane Cristina Deckmann. Sentir, adoecer e morrer: sensibilidade e devoção no discurso missionário jesuítico do século XVII. 1999. Tese (Doutorado em História) Programa de Pós-Graduação em História, Pontifícia Universidade Católica do Rio Grande do Sul, Porto Alegre, 1999. 
FLECK, Eliane Cristina Deckmann; DILlMANN, Mauro. A Vossa graça nos nossos sentimentos: a devoção à Virgem como garantia da salvação das almas em um manual de devoção do século XVIII. Revista Brasileira de História, São Paulo, v. 32, n. 63, p. 83-118, jan./jun. 2012.

FLECK, Eliane Cristina Deckmann; DILLMANN, Mauro. Os sete pecados capitais e os processos de culpabilização em manuais de devoção do século XVIII. Topoi, Rio de Janeiro, v. 15, n. 27, 2013 (no prelo).

HANSEN, João Adolfo. Educando príncipes no espelho. Floema, Vitoria Da Conquista, n. 2 A, p. 133-169, 2006.

HANSEN, João Adolfo. Introdução: Cartas de Antônio Vieira (1626-1697). In: . (Org.). Cartas do Brasil. São Paulo: Hedra, 2003.

LEAL, Catarina Cunha; FERREIRA, Manuela Almeida. Cuidados de higiene e de saúde em uma comunidade monástica do século XVII: o caso do Mosteiro de Santa Clara-a-Velha de Coimbra. Portugalia, São Paulo, v. 27/28, p. 89-118, 2006/2007.

LIMA, Luís Filipe Silvério. O tempo de Vieira: o espiritual e o humano no V Império. Cadernos de Criação, São Paulo, v. 27, p. 200-207, mar. 2002.

MACFARLANE, Alan. História do casamento e do amor. Inglaterra, 1300-1840. São Paulo: Companhia das Letras, 1990.

MANCERA, Sonia Corcuera de. Del amor al temor: Borrachez, catequesis y control en la Nueva España (1555-1771). México: Fondo de Cultura Económica, 1994.

MARTINS, Ana Maria Almeida (Org.). Como é diferente o amor em Portugal... Lisboa: Instituto da Biblioteca Nacional e do Livro, 1994.

MARTINS, William de Souza. Representações femininas na obra do padre Manuel Bernardes (1644-1710). Lócus: Revista de História, Juiz de Fora, v. 17, n. 2, p. 35-55, 2011.

MASSIMI, Marina. Antônio Vieira e a medicina da alma. Fundamentos teóricos e aplicações na obra sermonística. 2009. Disponível em: $<$ http://iiiseminariofariasbrito.blogspot.com.br/ 2009/08/antonio-vieira-e-medicina-da-alma.html>. Acesso em: 10 jun. 2013.

MASSIMI, Marina. Palavras, almas e corpos no Brasil Colonial. São Paulo: Edições Loyola, 2005.

MAZIERO, Diana. A "fineza do amor" no Teatro Sacro-Retórico-Exemplar do padre Antônio Vieira (em catorze sermões escolhidos para este fim). 2004. Dissertação (Mestrado em Teoria Literária) - Universidade Estadual de Campinas, Campinas, 2004. 
MIRANDA, José Américo; BOECHAT, Maria Cecília. Sermão do mandato. Eusébio de Matos, 1629-1692. Belo Horizonte: UFMG, 1999.

MONTEIRO, Rodrigo Bentes. As reformas religiosas na Europa moderna. Notas para um debate historiográfico. Varia Historia, Belo Horizonte, v. 23, n. 37, p. 130-150, jan./jun. 2007.

MOTT, Luiz. A revolução homossexual: o poder de um mito. Revista USP, São Paulo, n. 49, p. 40-59, mar./maio 2001.

NASCIMENTO, Carlos Arthur Ribeiro do. A religião na Suma de teologia de Tomás de Aquino. Projeto História, São Paulo, n. 37, p. 85-93, dez. 2008.

ORTEGA Y GASSET, José. Estudios sobre el amor. Madri: Revista de Occidente, 1958.

PACHECO, Luis Carlos de Lima. Iniciação cristã na Igreja Antiga. Paralellus, Boa Vista, ano 1, n. 2, p. 161-181, dez. 2010.

PÉCORA, Alcir. Teatro do Sacramento. São Paulo, Edusp/Ed. UNICAMP, 1994.

POLETTO, Roberto. Medicina acadêmica espanhola: continuidades de práticas mágicopopulares e avanços científicos em tratados de medicina do século XVIII. Trabalho de Conclusão do Curso (Graduação em História) - Universidade do Vale do Rio dos Sinos, São Leopoldo, 2011.

PRIORE, Mary Del. História do amor no Brasil. São Paulo: Contexto, 2005.

PRIORE, Mary Del. Homens e mulheres: o imaginário sobre a esterilidade na América portuguesa'. História, Ciências, Saúde - Manguinhos, Rio de Janeiro, v. 8, n. 1, p. 98-112, mar./jun. 2001.

RAMOS, Luís de Oliveira. Do hospital real de todos os santos à história hospitalar portuguesa. Revista da Faculdade de Letras, Porto, v. 10, p. 333-350, 1993.

RODRIGUES, Teresa. Portugal nos séculos XVI e XVII. Vicissitudes da dinâmica demográfica. Cepese, Lisboa, 2007. Disponível em:<http://cepese.up.pt/ficheiros/ WP\%20TRodrigues\%202.pdf >. Acesso em: 28 mar. 2013.

SANTOS, Zulmira. Vícios, virtudes e paixões: da novela como "catecismo" no século XVIII. Península: Revista de Estudos Ibéricos, Lisboa, n. 3, p. 187-199, 2006.

SARAIVA, Antônio José. Discurso engenhoso. São Paulo, Perspectiva, 1985.

SEIDE, Márcia Sipavicius. O Sermão do Mandato: análise literária e adequação histórica. Polifonia, Cuiabá, n. 5, p. 87-104, 2002. 
SILVA, Paulo José Carvalho da. A dor de amor na medicina da alma da primeira modernidade. Revista Latino-americana Psicopatologia Fundamental, São Paulo, v. 11, n. 3, p. 475-487, set. 2008.

SILVA, Paulo José Carvalho da. Sobre um mal universal, Revista Latinoamericana de Psicopatologia Fundamental, ano 9, n. 3, p. 533-537, set. 2006.

SIMMEL, Georg. Filosofia do amor. São Paulo: Martins Fontes, 1993.

THOMAS, Keith. Religião e declínio da magia. São Paulo: Companhia das Letras, 1991.

VAINFAS, Ronaldo. Antônio Vieira: jesuíta do rei. São Paulo: Companhia das Letras, 2011.

VARAZZE, Jacopo de. Legenda áurea. Vida de santos. São Paulo: Companhia das Letras, 2003.

ZELDIN, Théodore. Os franceses e o amor. Revista L'Histoire/Seuil. Porto Alegre: L\&PM, 1992. p. 269-274. 